\title{
The Impact of Stock Price Volatility on the Performance of the Nigerian Stock Market for the Period 1990 To 2011
}

\author{
Cornelius M. Ojong \\ Department of Banking \& Finance, \\ Faculty of Management Sciences, University of Calabar, \\ P.M.B. 1115 Calabar, Cross River State, Nigeria. \\ Ogar Anthony \\ Department of Banking \& Finance, \\ Faculty of Management Sciences, University of Calabar, \\ P.M.B. 1115 Calabar, Cross River State, Nigeria. \\ Chris 0. Udoka \\ Department of Banking \& Finance, \\ Faculty of Management Sciences, University of Calabar, \\ P.M.B. 1115 Calabar, Cross River State, Nigeria.
}

\begin{abstract}
This study examines the impact of stock price volatility on the performance of the Nigerian stock market for the period 1990 to 2011. To achieve this objective data were gathered on macroeconomic variables such as stock price volatility, market capitalization, exchange rate, interest rate and inflation rate were captured for the purpose of analysis. The data were tested using the Elliot-Rothernberg-Stock Test, the Generalised Autoregressive Conditional Heteroskedasticity (GARCH) Test and the Granger Causality Test. The multivariate Johansen Cointegration Test was performed to establish the long run relationship among the variables. The Vector Error Correction Mechanism (VECM) under the framework of Vector Autoregressive (VAR) Model was used to estimate the short run relationship. The result of the GARCH test showed that volatility shocks in the Nigerian stock market were not quite persistent during the study periods. The result of the Cointegration test revealed that there exist long-run relationships among the variables in the model. The result of the Granger Causality test showed that stock price volatility granger caused market capitalization in Nigeria. The result of the short run estimation showed that stock price volatility is negatively related to stock market performance. It is recommended that there is need to ensure stability of the stock market, so as to boost and restores investors confidence in the market. Such confidence will lead to increased investment in the market.
\end{abstract}

\section{INTRODUCTION}

This work investigates the sway of stock price volatility on the routine of the Nigerian stock market. The increase or decline in price fluctuation stems from the changes in investors' attitudes in the market place. When new information is made available in the market it will lead to a rise in stock price fluctuation. The extent of the rise is estimated by the importance of the new information and the level of expectation placed on the new information by investors (Rajni \& Mahendra, 2007). Financial experts and economist founded theories on the causes of price fluctuation. For instance, Engle (1982) believe that price instability is cause the influx of 
modern and unforeseen information that modify likely proceeds on a stock. Whereas, the rest looked at changes in trading capacity, patterns or practices of trading which are the main focused by the variation in macroeconomic policies changes in investor's risk lenience and increase ambiguity as the cause of volatility(Rajni \& Mahendra, 2007). Indeed, stock market volatility has implication, which is mainly negative. Another way that it will have effect on the economy will be through investor expenditure. (McCluer, 1998; Campbell, 1996 Ludrigson \& Standel, 1999; Poterba, 2000; and Rajni \& Mahendra, 2007).

A decrease in the market of stock prices will wane investors' poise and thus force downwards investors' expenditure (Rajni \& Mahendra, 2007). Stock market volatility may also have an effect on business nest egg (Zuliu, 1995) and economic enlargement unswervingly (Levine \& Zervous, 1996). An increase in stock market fluctuation is interpreted as an increase in equity and as a result of these funds will be invested in assets that are less risky. This approach have been known to result in an increased charge to companies resources and as such new companies (new entrants) may accept this upshot as investors go round to acquiring stocks in largely, healthy recognise companies (Rajni \& Mahendra, 2007). The stock market will be useful sympathetic of fluctuation in the willpower of the cost of investment and in the assessment of asset allotment resolution. Policy makers consequently rely on market estimates of fluctuation as a measurement of the susceptibility of financial markets (Olowe, 1999). However, the presence of extreme fluctuation in financial market plays down the importance of stock prices as an indicator of the real value of an entity, a perception that is core to the concept of the informational competent of markets (Karolyi, 2001).

The recapitalization of the Nigerian banking and insurance industries in July, 2004 and September, 2005 respectively boosted the number of securities traded on the stock exchange, thus improving public awareness and faith in the stock market. Also, the Nigerian stock market is an emerging and inefficient one characterized by the time lag between information availability about a stock and its full reflection on the price of the stocks (Olowe, 1999). Poor infrastructural facilities in the country make it virtually impossible for information to flow freely and speedily to actual and potential investors.

Vacillation of stock prices is not disparaging per se and is a sign of market effectiveness in most stock markets. In a competent market, stock prices are a sign of available information. Thus, stock prices swing in response to new information. Any progress that can affect the firmness of the economy habitually have serious impact on the stock prices. In modern times, the Nigerian stock exchange has for all time lost point and the stocks have veteran razor-sharp decline. The unprecedented downturn of activities of several quoted firms which were attributed to certain factors such as exchange rate, inflation rate and interest rate have led to high level of volatility and fluctuation (both positive and negative) in stock prices of the Nigerian stock exchange.

The main dilemma with price instability that affects the financial market competence is disparaging surplus fluctuation that ends up in crashes and/or crises in pecuniary markets. In such circumstances, difference connecting stock built-in assessment and it's associated with market value and is important, and has several penalty. The recent global financial crises and associated declines in economic activities of stock market performance experienced by a number of emerging market economies has made it imperative to appraise the links between stock prices, it volatility and the performance of the Nigerian stock market. The general intent of this study is to investigate the volatility of stock price and how this volatility affects the performance of the Nigerian stock market. Specifically this work sought;

1. To examine the effect of stock price volatility on market capitalization in Nigeria.

2. To determine the persistent of shock on the performance of stock market in Nigeria. 
3. To determine the long run relationship between stock price volatility, exchange rate, interest rate, inflation rate and stock market performance in Nigeria.

\section{Research hypotheses}

Based on the research objectives the following research hypotheses were formulated

1. $\mathrm{H}_{0}$ : There is no significant relationship between stock price volatility on market capitalization in Nigeria.

2. $\mathrm{H}_{0}$ : There is no significant long-run relationship between stock price volatility, exchange rate, interest rate, inflation rate and stock market performance in Nigeria.

\section{Random walk theory}

\section{LITERATURE REVIEW AND THEORETICAL FRAMEWORK}

The random walk hypothesis is a financial theory which states that price in the stock market develop in accordance to a to random walk, (so much such that the price cannot be predicted). Theory is in lyric with the efficient market hypothesis. The concept is easily traced to (Ragnault, 1963; Bachelier, 1900) which contained same outstanding insight and commentary. Similar ideas were subsequently expanded by (Cootner, 1964 \& Fama, 1965)

Malkeil (1973) carried out his test by giving his students a hypothetical stock that was initial worth fifty dollars. A flip of coin was used to determine the price at which the stock closed daily, such that if the result was heads, stock price would close higher by half point, however, if the result was a tail, the stock would close at half point lower. Thus at every given time, the price had equal probability of closing lower or higher than the previous day. Trends or cycles were then determined from the test. He recorded the result in a chat and graph from which he then took to a chartist, a person who seeks to forecast movement in the future by analysing past trend based on the assumption that "history trends to recap itself" (Kean,1983). The chartist persuaded that they should immediately buy the stock and was disappointed by Malkeil confession that the result was based totally on flipping a coin. He went on to argue that this is an indication that the market and stocks could also be as random as the flip of a coin.

Similarly, the random walk hypothesis was performed in NBA basketball by psychologist they made a detailed study of all shorts made by philadephia 76ers over one and a half basket ball seasons. They found that no positive correlation exist between the previous short and the outcome of the next short. Economist and believers in the random walk hypothesis apply this to stock market returns being that the actual lack of correlation of past and present is seen easily. Thus, if the value of a stock rises one day, it cannot be predicted accurately by any market participant that it will go up again the next day. Just like a basket ball player with the "hit hand" can moss the next short, stocks can rise and fall at anytime making it completely unpredictable.

A non random walk hypothesis: However, there are other economist profesors and investors who are of the view that the market can be predicted to a certain degree. These group argue that prices may move in trends such that the direction of future prices could be predicted by studying past prices. There are some economic studies that lend support to their view and two professors have authored a book that tries to prove the theory wrong (Lo, 1999). Martin Weber a seasoned researcher in behavioural finance has performed several test and studies aimed at unhealthy trends in the stock market. In one of his research he observed the stock for ten years and discovered that within this period, stocks with a high price in the first five years tend to perform poorly in the next five years. This has been cited by Webber and other nonbelievers in the random walk theory and a key contradictor to the random walk theory (Fronlet, 2011). Webber ran another test that contradicted the random walk theory, this time 
he found out that stocks that have had an upward revision for earnings out performed others in the next six months. With this knowledge, investors can forecast what stock to leave in the market and which one to take out. The study opposes the random walk hypothesis because he is of the opinion that trend and other tips exist for forecasting the stock market. Similarly, in a book titled " A non-random walk Down wall street written by Professors of finance they prove it with what is called the simple volatility-based specification test, which is an equation that states:

$$
X_{t}=\partial+X_{t-1}+\rho
$$

Where;

$\mathrm{X}_{\mathrm{t}}$ is the price of the stock at time $\mathrm{t}$

$\partial$ is an arbitrary drift parameter

$\rho_{\mathrm{t}}$ is a random disturbance term.

With this formula they were able to input prices of stock over a number of years and study trends that have unfolded. Through the years, they found little incremental changes in the stocks. With this changes Mackinlay and Lo believe that the stock market can be predicted thus challenging the random walk theory.

\section{Literature review}

Indices in the financial system are unstable, thus causing fluctuations in reality and outlook. This is as a result of the volatile nature of the consistent component of the financial system (Wikipedia, 2008).

The daily decisions of the different component of the financial system being individuals, corporations, businesses and industries in fostering their going-concern objective are by no means less volatile. Thus fluctuations on the prices of stocks are always as a result of differing decisions on stock investment.

The stock market is one part of the financial system, which responds to a little uneasiness among the variables or system of the whole economy. The stock market also desires a goingconcern, which however, depends on factors that seldom remain stable overtime.

Volatility has been defined as a measure of dispersion around the mean or average return of a security (Wagner, 2007). It is also often times referred to as the standard deviation of the change in value of a security within a specific time period and is usually used to qualify the risk associated with the instrument over that time horizon (Wikipedia, 2008).

It is worthy of mention that financial transactions that take place in the stock market or stock exchange involve assets, which by nature have an extended time horizon relative to most goods transactions. This in turn makes the financial system more sensitive to uncertainty about the future (Koubi, 2008).

Stock price seldom stay the same over time and show a situation of anomaly on a specific stock if its price does so. This is due to transaction cost. Koubi's (2008) study on financial development observes that stock return volatility is directly related to the stock market performance and posits that transaction cost effect on stock prices volatility may be ambiguous, however and Pirouz (2007), Mala and Reddy (2007), and Wagner (2007) attest to this. This they did for a cross section of countries employing pooled data and coefficient. 
Wagner (2007), for example, records that there is a positive correlation between price volatility and stock market performance. Investigating this on developed economies of Canada, Australia and the United States, he opines that price volatility tends to decline as the stock market decreases and increases as the stock market rises. This is also the same with risk, he noted.

The return on a stock for an individual spurs the individual for a continuous and sustain investment in the stock market. It should, however, be noted that decisions of investors can affect stock market returns adversely and thus price volatility as well (Priouz, 2007).

Irrational behaviour from investors, both individual and institutional, novice and professional, can significantly affect stock market returns and price volatility (Priouz, 2007) as mentioned earlier. This is closely related to national culture dimensions as evidenced by Jegadeesh and Titman in Pirouz (2007). The authors proposed that above average returns can be made by investing with the momentum of the market. The momentum of the market, however, is associated with a variety of factors, ranging from household decisions to that of corporation, organizations and governments that are usually volatility.

The momentum of the market is also adversely and inversely affected by the inflationary rate of the entire economy given the monetary policy in operation at a given point in time (Mala \& Reddy, 2007). This will invariably affect the expectations of investors, and by extension affect the market performance.

The expectations of investors as regards stock returns can be hampered by price volatility which influences inflation (Adamgbe, 2006). Adaptive and rational expectations of these investors are nonetheless, based on a non-analytic method, which is taken care of by the notice of volatility based on information about a stock market is liberalised.

On the other hand, the expectations of investors, be it adaptive or rational, lead to volatility, which is mostly based on the impulse response functions of investors. Impulse response function can be described as the intuition in which an investor has in selecting a stock (Pirouz, 2007). Types of volatility as identified, include stochastic volatility, SABR Volatility, implied volatility, local volatility, volatility smile, volatility clustering.

Estimation of these volatilities is the least simple and constitutes a very vital characteristics on prices of stock in the stock market (Little, 2007). These types of volatility traverse general terminologies. On the other hand, the types of volatility affecting stock prices specifically, invariably, affecting stock market performance include historical and implied volatility (Little, 2007).

Poon (2005) presumes that historical volatility can be measured from past market prices. Docking and Koch (2005), explain that historical volatility also known as realised volatility is associated with a period of time, actually, two periods of time. Expatiating, they posit that the measure of the amount of randomness in a financial quantity at any point in time can be described a s historical volatility and assert that it is difficult to measure since it deals more with past stock prices that cannot be used for future investment decisions.

Wilmot (2007), quoting Desmond Fitzgerald, termed historical volatility as 'bouncy bouncy' and asserts that it is used to measure how active a stock price typically is over time. That is, the 
fluctuations in share prices. This volatility over a long period of time can show how well the stock market has performed.

Beside historical volatility, implied volatility also exists. Implied volatility is that level of volatility that will calculate a fair value of an option that is equal to the current trading option prices and reflect today's market perception of the future (Dynamic, 2008).

Implied volatility can be determined when looking at an option through the strike price, the expiration date of a transaction, the current stock price, and the stock dividend paid by the stock investment strategies (Poon, 2005).

In other words, implied volatility explains the nature of the recent trend of the stock market and can be affected by government regulation, legislation, monetary policy, decisions of households, firms, investors, exchange rate, to mention a few, given how the market has been liberalised and the general level of prices (Nasseh \& Strauss, 2000).

Implied volatility is very important in that it tends to be a leading indicator of stock direction. For instance, it is posited by (Caldwell, 2004) that when a stock falls the implied volatility does not change and the market does not show this. Conversely, if the implied volatility rises, then the market is nervous about the stock's downside potential.

A stock's downside potential implies that the stock market and its returns are declining and this implies risks taken by investors since volatility implies risk that is associated with the degree of dispersion of returns around the average (Wagner, 2007).

Furthermore, volatility is important to be noted as it traverses all spheres of investment, especially, investment in the stock market, which is of the type investors commit monetary or other resources forward subjecting themselves to future risks (Magnus \& Fosu, 2006). It needs to be mentioned that almost all risks associated with financial assets derive their bearing from volatility of varied economic indices. The impact of volatility on the stock market can be likened to a pendulum that swings back and forth as illustrated by stock prices noticed from market reports.

In a typical stock market report, looking at the price columns for each stock in each sector, it could be observed that prices seldom stay the same on as little as on a day-to-day basis (Chukwuogor, 2007). This hitherto, is as a result of the volatile nature of the constituents of the stock market and the most vital of this is information (Teresiene, Aarma \& Dubaukas, 2008).

The impact of information that comes up inadvertently on individual stock prices cannot be over-emphasised, most especially that of a company in trade (that is, a company whose stocks are listed) on the floor of the exchange. Be it positive information, the stock's price reacts and if negative, the stock's price reacts all the same (Catao, Fostel \& Kapur, 2007).

In a nutshell, investors do not need to lose sight of volatility, though its measurement is said to be tricky, given the unquantifiable items that mostly cause a price shift. This, however, can be taken care of by the foremost Black Scholes Model (Wikipedia, 2008). In addition volatility presents itself on all economic indices and the reaction of the Nigerian stock market to the volatility of macroeconomic indices forms the interest of this current study as derived from literature, volatility of economic and financial indices reacts on stock prices and stock market performance. 
Imoyo (2007) challenged Oluba's (2008) assertions noting that the Nigerian market has ignored major fundamentals after having an unprecedented and undaunted 'roller-coaster'. This, Imoyo (2007), observed for fundamental strong companies in fundamentally strong sectors who still continues to do well as compared to the rest of the market and attributes this to effective monitoring of macroeconomic indices that gives rise to sector imbalance in the stock market. In other words, a downturn can occur in the market but would not affect fundamentally strong companies as a result of some investors buying shares due to market hear-say, thus arbitraging on stock with go prospects.

\title{
Research Design
}

\section{RESEARCH METHODOLOGY}

A research design can be viewed as the structure of a study. It can also be seen as the blueprint of the study that defines clearly how the parts of the study work in harmony to achieve the laid out objective(s). The appropriateness of the research design enhances the quality of any research to be carried out. Therefore, this study was both descriptive and historical in nature as it sought to describe the pattern of returns of the Nigerian Stock Exchange (NSE) in the past.

\section{Techniques of data analysis and Model Specification}

Various tools were applied on the time series data collected for this study. First the ARMA test was applied to ascertain the relationship between market capitalization and its lagged values. The study also applied the ARCH and GARCH models to estimate the conditional variance of Nigerian annual stock returns. Furthermore, ERS was used to test for the non-stationarity of the variables. Other tests conducted by this study were the cointegration and VAR tests.

In order to estimate volatility and predictability of stock prices in Nigeria stock market, it was necessary to specify the model that was utilised to analyse the data. The market capitalization will be used as a proxy for performance indicator of the Nigeria stock market and as such was the dependent variable. The independent variables utilised in this study were stock price volatility, exchange rate, interest rate and inflation rate are taken as proxy for stock price. The model thus;

$$
\begin{aligned}
& \Delta \operatorname{LogMCAP} P_{t}=\alpha_{0}+\alpha_{1} \Delta L o g p_{-} v_{\text {ol }}+\alpha_{2} \Delta \log E X C H_{t}+\alpha_{3} \Delta \operatorname{LogIR}_{t}+\alpha_{4} \\
& \Delta \operatorname{LogINFLA}_{t}+\alpha_{5} \sum_{k=1}^{p} \beta_{i} \Delta \log _{-} \operatorname{vol}_{t-k+} \alpha_{6} \sum_{k=1}^{q} \mu_{i} \Delta \operatorname{LogEXCH}_{t-k}+\alpha_{7} \sum_{k=1}^{r} \varphi_{i} \Delta \operatorname{LogIR}_{t-k+} \alpha_{8} \sum_{k=1}^{s} \Omega_{i} \\
& \Delta \operatorname{LogINFLA} A_{t-k} \mathbf{e}_{\mathrm{t}}
\end{aligned}
$$

Dependent variable is MCAP $=$ Market capitalization

\author{
Where \\ $\alpha 0=$ Constant \\ $\alpha 1$ to $\alpha 8, \beta \mathrm{i}, \mu \mathrm{i}, \Omega \mathrm{i}$ and $\varphi \mathrm{i}=$ Model parameters \\ $\Delta$ Log $=$ First difference of logarithm \\ The following are the independent variables \\ $\mathrm{P}-\mathrm{VOL}=$ Stock price volatility \\ $\mathrm{INF} \quad=$ Inflation rate \\ INTR $=$ Interest rate \\ EXCHR $=$ Exchange rate \\ $\mathrm{e}_{\mathrm{t}}=$ Stochastic error term \\ 4.0 Analysis and discussion of findings
}




\section{DATA ANALYSIS}

The ARMA test was performed to establish the stationary nature of the dependent variable (MCAP). Only the first difference operator was considered directly in the estimation specification. The optimal order of ARMA term was taken to be ARMA $(2,1)$. This means that there were two autoregressive terms and a single moving average term. Since it is known that only general results are interpreted for ARMA, we employed only the F-Statistics and not individual statistics in our interpretation. From the result obtained, one can reach the conclusion that the overall ARMA model is statistically significant given the high value of FStatistics (223.6462) and zero value of its probability. Similarly, the analysis of the inverse root of ARMA polynomials shows the invertibility and stationarity of the ARMA model. This is so because as revealed from the ARMA correlogram result, none of the root was found to rally around the acceptable region. It is therefore safe to say that, the current value of MCAP indeed depended on its lagged values.

The GARCH test was also carried out primarily to ascertain the volatility shocks persistency over time. It was carried out without imposing any restrictions either on the parameters or variance targeting. From the result obtained, the R-square, is negative due largely to the absence of regressors in the mean equation (Startz, 2009). Consequently, adding the coefficients of ARCH and GARCH $(0.289091+0.132105=0.421196)$, is very far from one. This is a strong statement that the Nigerian stock market volatility shocks were not quite persistent during the study periods. Thus, we can conclude that volatility shocks in the stock market were not persistent.

Taking consideration of the time series nature of the data used for estimation, it is certainly possible that we may obtain spurious results. To overcome this problem, stationarity test was conducted on the series using the Elliot, Rothemberg and stock test. The result of the Elliot, Rothenberg-stock unit root test shows that two variables ( $\mathrm{p}$-vol and interest rate) were stationary at levels. This is so because its ERS test statistic of 2.635900 and 1.397448 is less than the critical values of 1.870000 at one per cent, 2.970000 at five per cent and 3.910000 at 10 per cent. Except for interest rate and stock price volatility, all other variable were found not to stationary at levels. However, all variables were not stationary at 1 percent level when the series was differenced. Meaning that, the order of integration was 1(1) when the series was differenced once.

The integration of the series of the second order suggests that the variables of study exhibit the presence of a long-run relationship. By establishing this long run relationship, we employed the Johnansen multivariate cointegration as presented in appendix (6). The cointegration tests as presented in appendix (6) using both the trace and maximum-eigenvalue tests revealed two cointegration equations at 5 percent level. This is because their trace and maximum-eigen statistic values for the two cointegration equations exceed the 5 per cent critical value indicating the presence of the long-run relationship among the variables.

The long-run estimates as presented by the result shows that stock price volatility and interest rate have a positive and significant long-run relationship with market capitalization. Specifically, a 1 percent increase in both stock price volatility and interest rate will lead to a 1.33 percent and a 0.12 per cent increase in MCAP respectively in the long-run. As expected, there was a long-run significant negative effect on MCAP by both exchange rate and inflation. The results revealed a 1 percent increase in both exchange rate and inflation decreases MCAP by 0.03 per cent in the long run. 
Since we have been able to establish the existence of the long-run relationship among the variables of interest, we proceeded to perform the causality test to determine the causality directions among the variables. After critical assessment using the Akaike Information Criterion (AIC), 2 lags were utilized for the test. The results indicated a uni-directional relationship between the stock market volatility and market capitalization. From the results obtained, it means that it is stock price volatility that granger causes market capitalization but not the other way round. Based on the granger causality test result, the significance effect of the stock market volatility on the Nigerian quoted stocks' performance during the reference periods. Further examination also reveals a uni-directional relationship between: inflation and exchange rate; inflation and stock price volatility; market capitalization and interest rate; and exchange rate and market capitalization. This is established based on the fact that the probability values in these equations are less than 0.05 in the respective equations.

The short-run error correction model (ECM) estimates are estimated under the framework of VAR model. As shown by the results, only one out of the five models has a fairly good fit, given the values of R-squared in this model. The remaining four models have poor fits. Meanwhile further examination of the five models showed that only one model (Market Capitalization model) was statistically significant. This is so because the F- statistics value. The remaining models were not statistically significant as their F- statistics calculated were all less than the critical values at 5 per cent significant level.

However, focusing our attention on the stock market performance model, the result of the short-run dynamics indicated that the ECM coefficient was correctly signed and judged to be statistically significant. As can be seen from the result, about 35 per cent speed of adjustment to the equilibrium was witnessed in one year. The 0.701 value of the R-squared indicated that the explanatory variables have explained about 70 per cent of the total variations in stock market performance in Nigeria. The F-statistics value (4.302) also showed that the explanatory variables collectively were significant in explaining short-run changes in stock market performance in Nigeria. The short-run estimates showed that previous two period's value of market capitalization has negative impact on the current value of market capitalization. Surprisingly, stock price volatility is negatively related to stock market performance. A per cent increase in stock price volatility leads to a 0.03 per cent decrease in stock market performance in Nigeria, ceteris paribus. Similarly, the negative effect of interest rate on MCAP is in consonance with theoretical expectation, indicating a decrease in stock market capitalization by 0.03 percent other variables held constant.

Contrary to a priori expectation, inflation rate has positive relationship with stock market performance and inconsistence with theoretical expectation. However the result showed a per cent increase in the value of inflation will increase stock market capitalization by 0.005 percent other things remaining the same. Lastly, the positive effect of exchange rate is also in consistence with the theoretical postulation. The positive sign of the exchange rate coefficient shows an increase in stock market performance by 0.15 percent, other things being equal.

\section{DISCUSSION OF MAJOR FINDINGS}

The result of the short run dynamics showed that there exists a positive relationship between stock price volatility and market capitalization in Nigeria. A negative relationship between them may attribute to the under-developed nature of capital markets in the developing countries, including Nigeria. 
As shown in the result, interest rate impacted negatively on stock market performance. This was consistent with Aurangzeb (2012). The negative impact of inflation on stock market performance is inconsistent with the theoretical belief that an inflationary condition devalues the purchasing strength of money. This is inconsistent with the Fama's proxy hypothesis because under high inflation, stocks and other financial assets fail to keep up with the increase in the prices of goods.

Also high inflation creates volatility in stock market returns, which usually leads to the collapse in the stock values. For exchange rate, theoretical background has established that exchange rate has two kinds (positive and negative) impact on stock market but this study revealed a negative effect.

Statistically, only one out of the four explanatory variables was statistically significance, which is the interest rate. The variable was significant at 10 per cent significant level. On this note, it is concluded that interest rate have significantly impacted on the performance of the Nigerian stock market. In addition, the two period lagged value of market capitalization, inflation rate, price volatility, and exchange rate were not statistically significant because their t-statistic value calculated were all below the critical values at 5 and 10 per cent significant levels. This means that market capitalization, inflation rate, price volatility, and exchange rate were in influencing stock market performance in Nigeria.

\section{Summary of findings}

SUMMARY OF FINDINGS, CONCLUSION AND RECOMMENDATION

This research study was undertaken to examine the effect of stock price volatility on the performance of the Nigerian stock market. Various estimations as well as tests have been performed on the specified model and the major findings from the various estimations and tests are highlighted as follows;

The test conducted on the dependent variables (MCAP) showed that the model was statistically significant and hence its accuracy cannot be doubted. In the same vein, the analysis of the inverse root of autoregressive moving average polynomials showed that the model is stationary and invertible since none of its roots was found outside the unit circle.

The test was conducted to test the degree of persistency that the volatility of stock price exhibits and its effect on the quoted stock performance; it showed that the volatility shocks in the Nigeria stock market were not quite persistent for the period under review.

The unit root test using Elliot- Rothemberg and Stock test revealed the non-stationarity of the series at levels but became stationary when the series was difference once. Since the series was integrated of order 1(1), cointegration test was conducted. The revelation of the presence of the long-run relationship among variables came into effect through the results obtained from the cointegration test.

A unidirectional causality relationship was revealed from the Granger causality test between the volatility of the stock price and market capitalization (MCAP). There were also unidirectional relationship between market capitalization and interest rate. This was also the case for exchange rate and market capitalization; inflation and stock price volatility; and inflation to exchange rate. 


\title{
CONCLUSION
}

It was the thrust of this study to examine and determine the effect of stock price volatility on the performance of Nigerian quoted stocks. Stock markets in the world are known to play a vital role by helping to allocate funds efficiently to end users for investment purpose. However, several risk factor have been identified which financial experts believed posed serious problem to the efficient workings of the stock market. One of such risk is stock price volatility. Stock price volatility has real wealth effect on consumer spending as well as dampening of consumers' confidence. Whether this risk has affected the performance of the Nigerian stock market was the main objective of the study.

Based on the result obtained, it is found that stock price volatility has negative and insignificant impact on market capitalization. The result also found that exchange rate and inflation rate have positive and insignificant relationship with market capitalization, whereas the effect of interest rate on stock market performance was seen to be significant but negative. In general, the result obtain from the GARCH test showed that stock price volatility has not had persistent shock quoted stock in Nigeria during the study periods. We can therefore conclude that stock price volatility has not enough destabilizing effect on the performance of the Nigerian stock market, since the shocks arising from stock price volatility has no persistent effect on the quoted stocks in Nigeria.

\section{RECOMMENDATIONS}

In line with the analysis and results obtained in this study, it is therefore recommended that:

The negative impact of stock price volatility on the on the stock market performance demands that concise and appropriate policies and reforms to be implemented aimed at encouraging investment in the stock market.

There is need to ensure stability of the stock market, so as to boost and restores investors confidence in the market such confidence, will lead to increased investment in the market.

A reduction in the rate of interest rate should be adopted and implemented since interest rate acts as alternative source of investment. This was due largely on the negative effect of interest rate on the dependent variable.

Meanwhile, the positive effect of inflation on stock market calls for policies to reduce inflation rate to a single digit. This is because under high inflation, stocks and other financial assets fail to keep up with the increase in the prices of goods, leading to the collapse in the stock values.

Lastly, stabilization policy on the movement of exchange rate should be carried out owing to the positive effect it has on the stock market performance in Nigeria.

\section{References}

\author{
Abdalla, I. S. \& Murinde, U. (1997). Exchange rate and stock prices interaction in emerging financial markets evidence \\ on India, Korea, Pakistan and the Philippines. Applied financial Economics. 7(1), 25-35 \\ Adamgbe, E. T. (2005). Price volatility, expectations and monetary policy in Nigeria. Retrieved on 18/11/2009 from \\ emmaadamgbe@yahoo.com
}

Adekanye, F. (1986). The element of banking in Nigeria. London: Graham Burn.

Akinnifesi, O. E. (1987). The role and the performance of the capital market. Journal of Nigeria Institute of Social and Economic Research.1 (2), 14-18. 
Amadi, S. N., Onyema, J. I. \& Odubo, T. D. (2002). Macroeconomic variables and stock prices. A multivariate analysis. Africa Journal of Development Studies, 2(1), 159-164

Andrei, S. (2000). The informational content of implied volatility. Review of Financial Studies. 6, (1) 659-68.

Annot, R. (2008). Market-cap weighting: the problem and building on fundaments. Retrived on 18/11/2009 from http/www.invescopowershares.com

Anyanwu, J. C. (1998). An econometric investigation of the determinants of foreign investment in Nigeria: Rekindling investment for economic development in Nigeria. Nigerian Economic Society. 219-241.

Arghyrou, M. G., Gregoriou, A. \& Kontonikas, A. (2005). Do real interest rates converge? Evidence from the European Union. Working Papers, 7(21), Business School - Economics, University of Glasgow.

Ayadi, F. O. (1984). The random walk hypothesis and the behaviour of share prices in Nigeria. Nigeria Journal of Economic and Social Studies, 26(1), 57-71.

Bahmani-Oskoee, M. \& Sohrabian, A. (1992). Stock price and effective exchange rate of the dollar. Applied Economics. 24(5). 459-464.

Bhalla, O. (2010). The small world of investing: board connections and mutual fund returns. NBER WP, 13,121

Bollerslev, T. (1986). Generalized autoregressive conditional hetero-skedasticity. Journal of Econometrics, 31(3), 307328.

Brealy, R.A. \& Myers, S.C. (2003). Principles of corporate finance. Retrived from http://ebookbrowse.com/principles-ofcorporate-finance-brealey-myers-7th-ed-pdf-d138508468

Brown, T. (2008). Stock analysis for value investing: The price earnings ratio. Retrieved on 6/12/2009 from http/www.stockmarketnigeria.com.

Caldwell, M. (2004). How Does a Slow Economy Affect Investing Strategy? Retrieved on 23/11/, 2009 from http/www.moneyfor20s.about.com

Campbell, D. B. (1996). Filtering and forecasting with miss-specified ARCH models: Making the right forecast with the wrong model. Journal of Econometrics. 67, 303-335

Catao, I., Fostel, A. \& Kapur, S. (2007). Persistent gaps volatility types and default traps. Paper PRESENTED at the Conference on New Perspectives on Financial Globalization". Research Department, International Monetary Fund. April 10.

Chukwuogor, C. (2007). An econometric analysis of African stock markets: Annual returns analysis, day-of-the-week effect and volatility returns. African Journal of Accounting, Economics, Finance and Banking Research. 1(1), 26-43

Cootner, I. (1964). The information content of option prices and a test for market efficiency. Journal of Financial Economics. 6, (1) 213-234.

Desai, A. (2011). Herd behavior and contagion in financial markets. Mimeo: New York: University Publishers.

Dimitrova, D. (2005). The relationship between exchange rates stock prices: studied in a multivariate model. Issues in Political Economy 14(1). 101-123

Docking, D. S. \& Koch, P. D. (2005). Sensitivity of investor reaction to market direction and volatility: dividend change announcements. Journal of Financial Research, 28(1) 21-41

Dynamic Portfolio Limited (2008). Determinants of stock price movements in the secondary market. Retrieved from http:/www.dynamicportfolio.com

Engle, R. F. (1982). Autoregressive conditional heteroskedasticity with estimates of the variance of United Kingdom inflation. Econometrica, 55(1), 391-407

Fang, W. S. (2001). Stock market and expected depreciation over the Asian financial crisis. Applied Economics. 33(2). 905-912

Feldstein, M. (1983). Domestic saving and international capital movements in the long run and the short run. European economic review, 21(1), 129-51. 
Ojong, C. M., Anthony, O., \& Udoka, C. O. (2015). The Impact of Stock Price Volatility on the Performance of the Nigerian Stock Market for the Period 1990 to 2011. Archives of Business Research, 3(4), 78-92.

Fox, b. (2009). Are seasonal anomalies real? A ninety-year perspective. The review of financial studies, 1(4), 403-425 Fromlet, C. (2001). Security analysis and trading patterns when some investors Receive Information before Others". The Journal of Finance, 4(1)9, 1665-1698

Granger, W. J. (2007). Some comments on econometric methodology. Economic Record, 64, (4), 327-330 Hassan, Y. (2000). Predicting volatility in the foreign exchange market. Journal of Finance 50(1), 507-528 Imoyo, A. (2007). Nigeria stock market and companies: fundamentals. Retrieved on December 8, 2012 from http/www.bussinessday online.com

Ito, T. \& Yuko, A. (2004). High frequency contagion between exchange rates and stock market. Retrieved on Febuary 26, 2009 from http/www.egu.edu

Keane, O. (1983). The adaptive market hypothesis: Market efficiency from an evolutionary perspective. Journal of Portfolio Management. 30(1), 15-44

Kearney, C. (1998). The causes of volatility in a small internationally integrated stock market of Ireland July. Journal of finance Research, 21(1), 85-104

Kendall, D. \& Bradford, I. (1953). Day of the week effects and asset returns. Journal of Business, 31(1), 579-596

Kleinberg, M. \& Tardos, J. (2005). The only game in town: stock-price consequences of local bias. NBER Working Papers 11488, National Bureau of Economic Research, Inc

Koponen, I. A. (2003). The incremental volatility information in one million foreign exchange quotations. Journal of Empirical Finance 4(1), 317-340

Koubi, V. (2008). On the determinant of financial development and stock returns. Retrieved on May 16, 2009 from http/www.eurojournals.com

Kotoulas, G. \& Kryzanowski, L. (1996). Macro factor conditional volatility, time varying risk premium and stock return behavior. Financial Review, 31(1), 169-195.

Lee, M. C., Ready, J. M. \& Seguin, P. J. (1994). Volume, volatility and New York stock exchange. The American Finance Journal, 49 (1), 183-185

Leon, N. K. (2008). The effects of interest rates volatility on stock returns and volatility: evidence from Korea". International Research Journal of Finance and Economics. 14(8) http/www.eurojournals.com

Levine, R. \& Zervous, S. (1996). What we have learnt about policy and growth from cross-country regressions? American Economic Review, 83(2) 426-440

Little, K. (2007). Three main influence on stock prices. Retrieved on Febuary 3, 2009 from http/www.stocks.about.com.

Lowenstein, R. (2009). Financial development and economic growth: the role of stock markets. Journal of Money, Credit, and Banking, 33(1), 16-41.

Ludrigson, I. \& Standel, T. (1999). Finance and growth: is Schumpeter right? Quarterly Journal of Economics, 108(1), 717-737

Magnus, F. J. \& Fosu, E. O. (2006). Modeling and forcasting volatility of returns on the Ghana stock exchange using GARCH models. American Journal of Applied Sciences. 3(10), 2042-2048

Mala, R. \& Reddy, M. (2007). Measuring stock market volatility in an emerging economy. International Research Journal of Finance and Economics, 3(2). Retrieved on the June 6, 2009 from http/www.eurojournals.com.

Malkiel, B. (1973). A random walk down Wall Street. New York: Norton

Markowitz, H. M. (1991). Foundations of portfolio theory. The Journal of Finance, 46(2), 469-477.

Marquit, J. (2008). Interest rates and the stock market. Retrieved on April 13, 2013 form http/www.associatedcontent.com.

Mbat, D. O. (2001). Financial management. Uyo: Domes Associates. 
Mckinsey on Finance (2005). Do fundamental or emotions drive the stock market? Retrieved on April 13, 2013 from http/www.cfn.com.

Mclure, P. (2005). What are fundamentals? Retrieved on April 13, 2013 from http/www.investipedia.com.

Nasseh, A. \& Strauss, J. (2000). Stock price and domestic and international macroeconomic activity: a cointegration approach. Quarterly Review of Economics and Finance, 40(2), 229-245.

Nisan, A. \& Tardos, S. (2007).Testing market efficiency via decomposition of stock return. Application to Romanian capital market. Romanian Journal for Economic Forecasting, 3(1), 115-121.

Nocera, Y. (2009). Inefficient markets: An introduction to behavioural finance. New York: Oxford University Press.

Nwokoma, N. I. (2002). Stock market performance and macroeconomic indicators nexus Nigeria: An empirical investigation. Nigeria Journal of Economic and Social Studies, 4(1), 4-26.

Nzotta, S. M. (2004). Money banking and finance: Theory and practice. Owerri: Hudson Jude.

Odife, A. (2006). The message and methods of ethical investment. Journal of Cleaner Production, 11(1), 683-693.

Osaze, P. (2007). The performance of local versus foreign mutual fund managers. European financial management, 13(4), 702-720.

Olowe, R. A. (1999). Weak form efficiency of the Nigerian stock market: further evidence. African Development Review, 11(1), 54-68.

Oluba, M. (2008). Does Nigeria stock market efficiently reflect fundamental values? Swiss Management Center (SMC) Working Paper, 5(1), 16-27.

Ologunde, A. O., Elumilade, D. O. \& Asaolu T. O. (2006). Stock market capitalization and interest rate in Nigeria: a time series analysis. International Research Journal of Finance and Economic Issues, 4-2006.

Onoh, D. K. (2002). Dynamics of money, banking and finance in Nigeria: an Emerging Market. Lagos: Astra Meridian.

Pirouz, D. M. (2007). National culture and global stock market volatility. Retrieved on February 28, 2009 from http/www.meragesschoolofwusiness.com.

Poon, S. (2005). A practical guide to forecasting financial market volatility.New York: John Wiley and Sons.

Poterba, C. (2000). An empirical study on the relevance of applying relative valuation models to investment strategies in the Japanese stock market. Japan and the World Economy, 15(2), 331-339.

Rajni, M. \& Mahendra, R. (2007). Measuring stock market volatility in an emerging economy. International Research Journal of Finance and Economics, 8(1), 126-133.

Shen, P. (2000). The P/E ratio and stock market performance. Retrieved on July 28, 2010 from http:/www.ke.frb.org.

Siligardos, G. E. (2008). Interest rate and the stock market: The current state. Retrieved on April 5, 2009 from http:/www.traderslog.com

Smith, C. (1992). Stock market and exchange rate: A multi-country approach. Journal of Macroeconomics, 14(1), 607629

Soyode, G. (1993). Nigeria capital market and macro economic variables: An empirical analysis. Nigerian Journal of Monetary Economics.3.

Starr-McCluer, M. (1998). Stock market wealth and consumer spending. Finance and Economics Discussion Series. 3(1), 19-20

Startz, S. (2009). Commonality in liquidity. Journal of Financial Economics, 56(2), 3-28.

Tahir, R. \& Ghani, A. A. (2004). Relationship between exchange rates and stock prices: Empirical evidence from Bahrain's financial markets. Singapore: National University of Singapore Department of Economics

Teresiene, D., Aarma, A. \& Dubauskas, G. (2008). Relationship between stock market and macroeconomics volatility. Transformations in Business and Economics. 7(2) 102-114.

Wangner, H. (2007). Volatility's impact on market returns, Retrieved July 19, from www.investopedia.com 
Ojong, C. M., Anthony, O., \& Udoka, C. O. (2015). The Impact of Stock Price Volatility on the Performance of the Nigerian Stock Market for the Period 1990 to 2011. Archives of Business Research, 3(4), 78-92.

Wikipedia, the Free Encyclopedia (2008). Volatility (finance). Retrieved on August 17, 2009 from http:/www.en.wikipedia.org/wiki/volatility.

Wilcox, J. A. (1990). Nominal interest rate effects on real consumer expenditure. Paper Presented at the $31^{\text {st }}$ Annual Meeting of the National Association of Business Economists. San Francisco, March 16, 2007

Yu, Q. (1997). Stock prices and exchange rates: experience in leading East Asian financial centre Tokyo. Hong Kong and Singapore". Singapore Economic Review. 41(3). 47-56.

Zuliu, J.M. (1995). An investigation of transactions data for NYSE stocks. Journal of Finance. 60(1), 723-739. 